\title{
PENGUATAN POLA ASUH ORANG TUA DALAM MENGATASI KENAKALAN REMAJA DI KELURAHAN TAKOME KOTA TERNATE
}

\section{Mawardi Djamaluddin ${ }^{1}$, Suryani Hi. Umar ${ }^{2}$, Midin La Page ${ }^{3}$, Arni Khusnul Khatimah $^{4}$}

Program Studi Bimbingan dan Konseling Pendidikan Islam, Fakultas Tarbiyah dan Ilmu Pendidikan, Institut Agama Islam Negeri Ternate

\begin{abstract}
Abstrak
Pola interaksi dan komunikasi yang tidak terbatas telah mempengaruhi perubahan pola perilaku setiap individu. Pola perilaku tersebut dapat membentuk perilaku yang adaptif maupun maladaptif, hal yang juga berpotensi terjadi pada remaja. Terutama remaja yang hidup dana menetap di Kelurahan Takome. Takome sebagai sebagai satu kelurahan di Kecamatan Ternate Barat, Kota Ternate, Provinsi Maluku Utara merupakan tujan wisata favorit bagi masyarakat di Kota Ternate, sehingga hal ini berdampkan pada semakin beragamnya setiap orang yang datang dan berinteraksi dengan remaja-remaja di kelurahan Takome. Berinteraksi dengan orang baru merupakan sesuatu hal yang sangat bermanfaat karena dapat memberikan pemahaman yang beru bagi setiap remaja, namun pada sisi yang lainnya dapat memberikan potensi-potensi beruk terhadap perilaku negatif remaja jika tidak mampu menyaring berbagai informasi yang berdampak negatif bagi dirinya. Oleh karena itu, diperlukan program pengembangan potensi remaja untuk mencegah potensi-potensi kenakalan yang terjadi di Kelurahan Takome. Program Pengabdian Masyrakat dibagi dalam dua tahap, yaitu: tahap sosialisasi dan tahap pelatihan.
\end{abstract}

Kata Kunci: Pelatihan, Pola Asuh, Kenakalan Remaja

\begin{abstract}
Unlimited patterns of interaction and communication have affected changes in the behavioral patterns of each individual. The pattern of behavior can form adaptive and maladaptive behavior, things that also have the potential to occur in adolescents. Especially teenagers who live in funds settled in the Takeome Village. Takome as a village in the Western Ternate Subdistrict, Ternate City, North Maluku Province is a favorite tourist tour for the community in Ternate City, so this is echoed on the more diverse everyone who comes and interacts with teenagers in the Takome Village. Interacting with new people is a very useful thing because it can provide an understanding of every teenager, but on the other hand, it can provide potentials to bloom against adolescent negative behaviors if they are unable to filter out various information that hurt him. Therefore, the development program for the development of adolescent potential to prevent the potential for delinquency occurred in the Takeome Village. The community service program is divided into two stages, namely: Socialization and Training Stage.
\end{abstract}

Keywords: Training, parenting, juvenile delinquency

Correspondence author: Mawardi Djamaluddin, mawardidjamaluddin@iain-ternate.ac.id, Ternate, and Ternate

This work is licensed under a $C C-B Y-N C$ 


\section{PENDAHULUAN}

Tindakan anti-sosial yang dilakukan oleh remaja berbagaimacam bentuknya, mulai dari perilaku kecil yang tidak dapat diterima secara sosial seperti "tidak menghormati orang lain" hingga kejahatan besar seperti "pembunuhan, pemerkosaan, perampokan, dan pembunuhan bayi". Tindakan antisosial remaja kita selalu menarik perhatian publik, dengan bantuan media kita. Meskipun hanya sebagian kecil dari remaja kita yang terlibat dalam kegiatan negatif, terutama dalam kejahatan besar, tindakan kenakalan mereka membutuhkan perhatian perhatian kita yang mendesak karena mereka adalah masa depan kita. Psikolog, konselor, dan pekerja sosial cenderung bimbang antara definisi sosiologis dan psikiatri yang menghubungkan remaja dengan perilaku yang menyakiti orang lain dan / atau properti mereka. Para profesional ini cenderung memandang kenakalan remaja sebagai 'Gangguan Perilaku' berdasarkan Manual Diagnostik dan Statistik Amerika Edisi Keempat (DSM-IV-TR). 'Gangguan Perilaku' dideskripsikan sebagai "pelanggaran berulang atas hak pribadi atau hak milik orang lain dan ekspektasi dasar masyarakat". Terdapat banyak faktor yang mempengaruhi terjadinya kenakalan remaja, yaitu: karakteristik pribadi remaja, karakteristik demografis keluarga, fungsi keluarga, pengasuhan dan komunikasi, dan faktor sosial dan lingkungan (Bronfenbrenner, 2018). Kenakalan remaja mungkin memiliki kombinasi dari berbagai faktor yang berkontribusi pada perilaku mereka. Karakteristik pribadi atau atribut kenakalan yang ditemukan berhubungan dengan kenakalan meliputi: harga diri, keterampilan koping, religius, atribut kepribadian, prestasi akademik rendah, kegagalan sekolah dan buta huruf. Karakteristik keluarga meliputi faktor demografis serta sosioekologis keluarga remaja. Faktor-faktor tersebut antara lain: pendapatan keluarga, status sosial, kualitas hubungan keluarga, fungsi keluarga, kualitas parenting, kualitas pengawasan orang tua, kualitas komunikasi keluarga, struktur keluarga dan ukuran keluarga (Dumenci, 2017).

Faktor lingkungan termasuk pengaruh teman sebaya dan media. Pengaruh negatif teman sebaya dan media juga secara konsisten ditemukan berkontribusi pada kenakalan. Merokok, perkelahian antar geng, dan pembolosan biasanya dilakukan dalam kelompok. Pembukaan awal materi pornografi seperti buku dan video dilaporkan oleh remaja yang terlibat dalam kenakalan seksual. Potensi-potensi kenakalan remaja juga menjadi potensi tantangan yang dihadapi oleh masyarakat di Kota Ternate, salah satunya adalah kelurahan Takome. Seiring dengan berkembangnya masyarakat yang semakin kompleks, maka perubahan perilaku yang terjadi pada remaja merupakan hal penting perlu diantisipasi terutama berkaitan dengan perilaku negatifnya.

Berdasarkan pengamatan terhadap karakteristi kelurahan Takome yang merupakan satu kelurahan di Kecamatan Ternate Barat, Kota Ternate, Provinsi Maluku Utara, Indonesia memiliki karakteristik yang sama dengan kelurahan lainnya yang ada di Indonesia, Kelurahan Takome memiliki karakteristik sebagai daerah dengan karakteristik lingkungan alam yang indah sehingga menjadi salah satu tempat wisata yang favorit bagi masyarakat di Kota Ternate. Selain itu, kelurahan Takome juga memiliki nilai-nilai yang mempengaruhi pola perilaku masyarakatnya, yaitu nilai etika yang dijunjung tinggi karena kuatnya sistem hirarki sosial yang mempengaruhi etika dalam perilaku sehari-hari masyarakat setempat. Nilai sosial juga mempengaruhi pola komunikasi masyarakat yang relatif lebih kolektif dengan tersedinya balai desa/kelurahan sebagai ruang komunikasi publik dan juga pertemuan bagi masyarakat. Nilai keagmaan juga sangat dijunjung tinggi oleh masyarakat Takome terutama nilai- 
nilai keislaman yang termanifestasi dalam ritual-ritual kebudayaan masyarakat setempat. Takome sebagai salah satu kelurahan yang menjadi tujuan wisata masyarakat di Kota Ternate, menghdapi berbagaimacam tantangan yang berkaitan dengan potensipotensi menculnya kenakalan remaja yang terjadi pada generasi muda mereka, secara khusus pola perilaku remaja di kelurahan Takoma relatif positif dalam bentuk menginisiasi sejumlah aktivitas positif yang melibatkan partisipasi dari seluruh masyarakat. Walaupun demikian, tokoh masyarakat di Kelurahan Takoma menyadari bahwa untuk menjaga perilaku remaja maka diperlukan program yang efektif sehingga remaja memiliki kemampuan yang adaptof dalam mengarahkan perilaku mereka untuk selalu mengarahkan perilaku secara positif.

\section{METODE PELAKSANAAN}

\section{Waktu dan Tempat}

Sebelum kegiatan dilaksanakan maka dilakukan persiapan-persiapan sebagai berikut: Melakukan pengamatan dan wawancara dalam rangka menilai kebutuhan yang mendasar dari masyarakat kelurahan Takome yang berkaitan dengan pengembangan kajian keilmuan dari prodi BKPI, Mengajukan izin kepada pihak kelurahan untuk melaksanakan kegiatan PKM, Berkoordinasi dengan ketua BKM dan ketua karang taruna kelurahan Takome untuk mengudang peserta pelatihan, Menentukan waktu pelaksanaan dan lamanya kegiatan pengabdian bersama-sama tim pelaksana, serta Menentukan dan mempersiapkan materi yang akan disampaikan dalam kegiatan pengabdian masyarakat. Pelaksanaan kegiatan pengabdian berlangsung pada hari Kamis, 8 Oktober 2020 sampai Jumat, 9 Oktober 2020. Kegiatan dihadiri 20 orang tua dan 10 emaja yang berasal dari kelurahan Takome. Kegiatan pengabdian berlangsung di balai pertemuan kelurahan Takome. Kegiatan pengabdian diawali dengan sambutan dari Wakil DekanIII FTIK IAIN Ternate Dra. Suryani Hi. Umar, M.Pd., kemudian dilanjutkan denganpenyampaian materi tentang karakteristik remaja, bentuk-bentuk kenakalan remaja,dan pelatihan penerapan pola asuh yang efektif dalam mereduksi kenakalan remaja. Sebelumnya, dilakukan silahturrahmi dan diskusi dengan pihak terkait seperti Kepala Desa Sukodono, tokoh masyarakat, tokoh agama dan ketua pemuda Kelurahan Takome.

\section{Metode Kegiatan}

Metode kegiatan Pengabdian Kepada Masyarakat (PkM) terbagi menjadi dua metode utama, yaitu sosialisasi dan workshop. Metode sosialisasi dilakukan dengan menyajikan beberapa materi pokok yang sesuai dengan tema kegiatan Pengabdian Kepada Masyarakat $(\mathrm{PkM})$ yang dilaksanakan. Materi disampaikan oleh dosen yang juga berperan sebagai pelaksana kegiatan Pengabdian Kepada Masyarakat (PkM). Materi yang disampaikan terdiri dari: Penguatan Pola Asuh Orang Tua dalam Mengatasi Kenakalan Remaja, mencakup: Konsep dasar dan ruang lingkup pola asuh orang tua, Penguatan Pola Asuh Orang Tua, Bentuk-bentuk kenakalan remaja dewasa ini, dan Berlatih mengidentifikasi perilaku remaja. Sedangkan topik yang kedua adalah BentukBentuk Perilaku Kenakalan Remaja serta Cara Penanganannya, terdiri dari: Mengenal Gawai sebagai salah satu sumber proses pembentukan perilaku negatif pada remaja, Mengidentifikasi bentuk-bentuk perilaku kenakalan remaja yang sering terjadi, dan 
Menoptimalkan peran otak dalam membentuk perilaku positif. Kemudian dilanjutkan dengan metode yang kedua, yaitu workshop. Kegiatan workshop terdiri dari dua sesi, sesi pertama dilakukan dengan melatih orang tua dalam untuk menerapkan pola asuh yang efektif dalam mengetasi kenakalan remaja, kemudian dilanjutkan dengan sesi kedua yaitu pelatihan kepada remaja untuk mengidentifikasi potensi-potensi perilaku negatif remaja di masa dpan.

\section{HASIL DAN PEMBAHASAN}

Hasil yang dicapai pada kegiatan pengabdian masyakat ini dapat dikelompokkan menjadi dua, yaitu hasil yang diperoleh orang tua dan juga remaja.Bagi orang tua, diharapkan dapat memahami beragam pola asuh yang efektif dalam mengatasi munculnya potensi-potensi kenakalan remaja. Sedangkan bagi remaja, diharapakan dapat mengidentifikasi dampak-dampak pergaulan yang berpotensi mengarahkan mereka pada bentuk-bentuk perilaku kenakalan remaja. Selain itu, hasil yang diperoleh juga dapat diterapkan dalam tataran praksis, yaitu orang tua mampu menerapkan pola asuh yang efektif sebagaimana dilatihkan pada kegiatan workshop. Kemudian bagi remaja, ketermpilan yang diperoleh adalah kemampuan komunikasi yang efektif dalam berinteraksi dengan orang yang baru dikenal dalam rangka memproteksi dirinya.

\section{Tahap kegiatan sosialisasi}

Kegiatan sosialisasi dilakukan dengan memberikan materi yang disampaikan oleh Dosen kepada peserta kegiatan Pengabdian kepada Masyarakat (PkM), kegiatan ini juga melibatkan tokoh agama dan juga tokoh pemuda kelurahan Takome. Kegiatan PkM ini juga melibatkan mahasiswa prodi BKPI untuk memberikan pengalaman yang nyata kepada mahasiswa. Pada tahap ini, kegiatan dibagi menjadi dua bagian utama, yaitu sosialisasi yang diberikan kepada orang tua dan sosialisasi yang diberikan kepada remaja. Kegiatan sosialisasi kepada orang tua memuat materi yang terdiri dari: Konsep dasar dan ruang lingkup pola asuh orang tua, Penguatan Pola Asuh Orang Tua, Bentukbentuk kenakalan remaja dewasa ini. Sedangkan materi sosialisasi yang diberikan kepada remaja terdiri dari: Mengenal Gawai sebagai salah satu sumber proses pembentukan perilaku negatif pada remaja, Mengidentifikasi bentuk-bentuk perilaku kenakalan remaja yang sering terjadi, dan Menoptimalkan peran otak dalam membentuk perilaku positif.Kegiatan sosialisasi dengan format Seminar adalah teknik kelompok tingkat lanjut yang biasanya digunakan di pendidikan tinggi. Ini adalah teknik instruksional yang melibatkan menghasilkan situasi bagi kelompok untuk memiliki interaksi terpandu di antara mereka sendiri pada suatu tema. Ini mengacu pada diskusi kelompok terstruktur yang biasanya mengikuti kuliah formal atau ceramah sering dalam bentuk esai atau presentasi makalah tentang suatu tema. Oleh karena itu, melalui tahapan sosialisasi peserta kegiatan $\mathrm{PkM}$ memiliki pengetahuan yang mendalam terhadap materi yang disampaikan (Andrews, M \& Chilton, 2019).

\section{Tahap Workshop}

Pada tahap workshop ini kegiatan yang dilakukan pelatihan dalam rangka penguatan keterampilan yang dimiliki oleh peserta kegiatan PkM. Metode pelatihan ini dipilih dengan petimbangan bahwa seluruh prosedur, kegiatan, atau teknik yang digunakan bersifat sistematis yang dirancang untuk memberikan pengetahuan 
(knowledge), kemampuan (abilities), keterampilan (skills), atau sikap (attitudes) yang dimiliki peserta pelatihan. Kegiatan dibagi menjadi dua kegiatan utama, yaitu: kegiatan pelatihan yang diberikan kepada orang tua dan kegiatan pelatihan yang diperuntukan bagi remaja.

Kegiatan pelatihan yang diberikan kepada orang tua difokuskan pada penerapan pola asuh yang efektif dalam mengatasi kenakalan remaja, sedangkan materi pelatihan yang diberikan kepada remaja adalah kemampuan komunikasi efektif dalam berinteraksi dengan orang yang baru dikenal.

Perpaduan antara kegiatan sosialisasi dan workshop merupakan upaya untuk pengembangan dan penyampaian informasi yang dimana informasi tersebut dapat dikembangkan menjadi pengetahuan yang kemudian dikembangkan menjadi keterampilan yang dapat diterapkan, shingga peserta kegiatan $\mathrm{PkM}$ mampu mengintegrasikan pengetahuan (knowledge), kemampuan (abilities), keterampilan (skills), atau sikap (attitudes) secara komprehenisf. Strategi untuk untuk mengintegrasikan pengetahuan (knowledge), kemampuan (abilities), keterampilan (skills), atau sikap (attitudes) digunakan oleh pelatih atau instruktur sebagai media untuk menyampaikan pengetahuan, pengalaman atau informasi kepada peserta guna memfasilitasi pembelajaran serta mengarahkan mereka untuk mengubah perilaku dan sikap kerja mereka sesuai dengan tujuan pelatihan (Ballard, S. M. \& Carrol, 2015).

Proses kegiatan Pengabdian kepada Masyarakat (PkM) diberikan kepada orang tua dan juga remaja yang juga merupakan anak-anak mereka bertujuan untuk mengintegrasikan pemahaman dan keterampilan yang diperoleh dapat diterapkan dalam pola interaksi yang nyata dalam kehidupan mereka. Keterlibatan peserta pelatihan berupa orang tua dan anak-anak mereka yang berusia remaja ini dapat mencapai hasil yang optimal ketika orang tua memiliki metode yang efektif dalam menerapkan pola pendidikan yang sesuai dengan karakteristik perkembangan anaknya, sedangkan remaja memiliki kemampuan yang baik dalam menempatkan dirinya sebagi seorang anak. Hasil yang diperoleh dalam kegiatan PkM ini terlihat dari dua unsur utama, yaitu ketika orang tua memahami secara konseptual tugas dan tanggung jawab utama sebagai orang tua serta mampu menerapkan kemampuan yang memadai dalam menerapkan pola asuh yang efektif selama proses kegiatan pelatihan berlangsung. Sedangkan hasil yang diperoleh remaja terlihat dari pengetahuan mereka dalam mengidentifikasi bentukbentuk kenakalan remaja yang terjadi saat ini dan juga kemampuan remaja dalam menerapkan pola komunikasi yang efektif selama proses pelatihan. Keberhasilan dalam penepan polas asuh yang efektif diharapkan dapat memberikan dampak positif terhadap perkembangan psikologis remaja karena pola asuh orang tua merupakan salah satu variabel utama yang mempengaruhi muncul atau tidaknya kenakalan remaja, misalnya kehamilan remaja, penyalahgunaan zat, pembolosan, gangguan sekolah, prestasi rendah, pelecehan anak, ketidakmampuan untuk bekerja, kejahatan remaja, dan penyakit mental. Oleh karena itu, pola asuh orang tua memainkan peran penting dalam mencegah masalah kesehatan mental remaja (Carter, 2012).

Kegiatan Pengabdian kepada Masyarakat $(\mathrm{PkM})$ ini menekankan keterlibatan aktif dari seluruh komponen masyarakat di Kelurahan Takome dengan berkonsultasi dengan pihak Kelurahan Takome untuk menentukan peserta yang dilibatkan dalam kegiatan Pengabdian kepada Masyarakat (PkM). Kegiatan utama yang dilakukan sosialisasi dan workshop dengan materi kegiatan: Konsep dasar dan ruang lingkup pola asuh orang tua, Penguatan Pola Asuh Orang Tua, Bentuk-bentuk kenakalan remaja dewasa ini, Berlatih mengidentifikasi perilaku remaja, mengenal Gawai sebagai salah satu sumber proses 
pembentukan perilaku negatif pada remaja, Mengidentifikasi bentuk-bentuk perilaku kenakalan remaja yang sering terjadi, dan mengoptimalkan peran otak dalam membentuk perilaku positif.
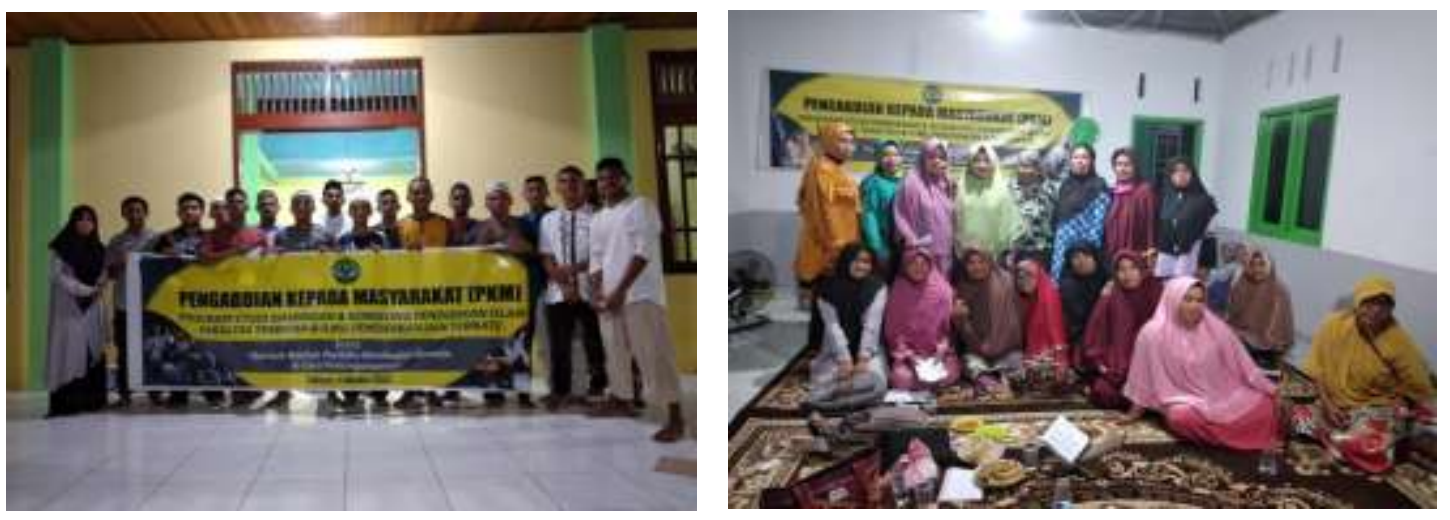

Gambar1 Kegiatan Sosialisasi dan Workshop di Kelurahan Takome

\section{SIMPULAN}

Kegiatan Pengabdian kepada Masyarakat $(\mathrm{PkM})$ yang dilakukan di Kelurahan Takome Kecamatan Ternate Barat, Kota Ternate, Provinsi Maluku Utara, difokuskan pada orang tua dan remaja sebagai komponen utama dalam upaya pencegahan berbagaimacam bentuk kenakalan remaja yang berpotensi terjadi di masa yang akan datang. Metode yang digunakan adalah kegiatan sosialisasi dalam bentuk seminar dan kegiatan worshop dalam bentuk pelatihan yang bertujuan untuk memberikan pemahaman yang komprehensif dan keterampilan yang memadai kepada seluruh peserta kegiatan PkM dalam rangka upaya pencegahan potensi-potensi kenakalan remaja yang dapat terjadi. Upaya untuk mengarahkan pola perilaku remaja yang adaftif sehingga memberikan manfaat bagi remaja untuk masa depannya, maka diperlukan dukungan dan partisipasi yang berkelanjutan dari semua pihak sehingga remaja dapat diwadahi melalui sejumlah kegiatan positif yang mengarah pada pengembangan potensi yang dimiliki.

\section{DAFTAR PUSTAKA}

Andrews, M \& Chilton, F. (2019). Student and mentor perceptions of mentoring effectiveness. Nurse Education Today, 20(3), 555-562.

Ballard, S. M. \& Carrol, E. B. (2015). Internship practices in family studies programs. Journal of Family \& Consumer Sciences, 97(4), 11-17.

Bronfenbrenner. (2018). Ecology of the family as a context for human development: Research perspectives. Developmental Psychology, 22(6), 723-742.

Carter, S. D. (2012). Matching training methods and factors of cognitive ability: A means to improve training outcomes. Human Resource Development Quarterly, $13,71-87$.

Dumenci, L. (2017). Ten-year comparisons of problems and competencies for national samples of youth: Self, parent and teacher reports. Journal of Emotional and Behavioral Disorders, 10(4), 194-203. 